\title{
Managerial silencing of employee voice
}

Jimmy Donaghey, Tony Dundon, Niall Cullinane, Tony Dobbins and Eugene Hickland

in P. Holland, J. Teicher and J. Donaghey (Eds.) (2019), Employee Voice at Work, New York: Springer (ISBN 978-981-13-2820-6, pp.113-128)

\section{Introduction}

Employee voice has become an issue of much focus in contemporary industrial relations, human resource management and organisational behaviour literatures. Much of the focus has been concerned with evaluating the different forms and processes of voice in terms of its alleged efficacy, worker representation and performance. This chapter however will look at what may be regarded as the antithesis of employee voice: worker silence. As will be outlined, the literature to date has been dominated by scholars from organisational behaviour, and to a lesser extent labour process and critical management studies research. However, this chapter will show that employment relations scholarship can make a valuable contribution to this area by focussing on how management silence workers. To do this, the chapter will review briefly the literature on worker silence to date and highlight some key weaknesses. It will argue how an employment relations perspective can be instructive about worker silence and in particular the neglected role of management in silencing worker voice. After outlining the nature of our study's focus on the implementation of the EU's Information and Consultation Directive in the UK and Ireland, the data will show how management responded in three cases to avoid elements of the Directive to prevent worker voice, i.e. how management acted in silencing workers. The chapter will close by discussing the implications of the analysis. 


\section{A Review of the Literature on silence and relationship to voice}

Worker voice is the latest term which has come into fashion to describe various types of management-worker interaction. While for a period, employee involvement and participation was used to describe worker inclusion around work tasks and the like, the term voice is perceived to be broader and includes direct and indirect participation including issues of representation (Wilkinson et al, 2014). Research into voice has highlighted the myriad meanings associated with the term (Dundon et al, 2004). Without doubt its meaning varies greatly. For example, Morrison (2011) associates worker voice with being pro-social, individual and informal in nature. As such, voice is understood as workers directly communicating with management with a mind to improving business operations. This approach has been criticised by Barry and Wilkinson (2016) as being partial as it only considers voice in terms of the extent to which it aligns with what management wants and fails to recognise the fact that competing interests are central to the employment relationship. These distinctions will not be laboured in this chapter. Rather the point is that the literature to date on silence has been dominated by the more organisational behaviour approach, with rather limited attention from those of a more pluralist and radical orientation. However, this may be due to a methodological issue: how do researchers identify incidents of where workers have not been able to speak up about issues as to their concern? As such, the chapter will put forward the concept of managerial silencing as a method of understanding the voice-silence dynamics of the employment relationship.

\section{Organisational Behaviour: The emergence of worker silence}

Research into employee silence first emerged from scholars in the area of organisational behaviour where silence has been generally conceptualised as the conscious withholding of information by 
workers, with an in-built assumption that voicing concerns is an alternative choice. It is therefore a communicative choice which employees may decide to adopt. Morrison and Miliken (2000) introduced the concept and highlighted silence as a situation of when workers consciously decide to withhold information from managers which could be of benefit to the organisation. Two key features are important to highlight from their approach. The first of these is that the information withheld is information which otherwise would be useful to management in pursuit of the interests of management. Secondly, the information is intentionally withheld by workers which carries with it an assumption that there is an avenue through which workers could pursue their voice were it not for their choice to withhold. They particularly focussed on developing an argument that organisations developed 'systematic cultures' of silence where employees do not express their ideas and do not speak the truth due to a fear of negative repercussions and/or to beliefs that their opinions are not valued (see also Pinder and Harlos, 2001). A particular issue highlighted was employees were very focused on what they saw as the potential negative outcomes, or risks, of speaking up (Miliken et al, 2003): The desire to avoid negative outcomes influenced significantly their decisions to remain silent. Furthermore, employee silence was seen to stem from a reluctance to convey negative information because of the discomfort associated with being the conveyer of bad news and the effect this may have on a worker's image to management and their peers at work (cf. Morrison and Rothman, 2009). There are seen to be powerful norms within the workplace that often prevent employees from saying what they know. In this research, many respondents expressed concerns about damaging relationships or fear of retaliation and punishment, such as losing their job or not getting a promotion (c.f. Miliken et al. 2003: 1462).

While this approach has been criticised for its overly managerialist approach, it certainly brings attention onto the issue of workers maintaining silence and some sources of such silence. However, the biggest weakness of this approach is that, with the exception of inappropriate actions by 
individual managers, it fails to examine the role which managers may play in creating silence. In fact, Pinder and Harlos (2001) defined employee silence as withholding genuine expressions about behavioural, cognitive, and/or affective evaluations of organisational circumstances to people who seem capable of changing the situation, i.e. there is an assumption that managerial interests and workers interests align in such situations. Indeed silence tends to be conceptualised in a fashion of withholding ideas, information and opinions with relevance to improvements in work and work organisation (Van Dyne et al. 2003) and where "new ideas facilitate continuous improvement" (Van Dyne and Lepine, 1998)._The position presented in this chapter is based upon an assumption that there will be circumstances in which management wish for employees to be silent. As such, the mechanisms through which voice is channelled are not neutral: they have highly political consequences. Thus, the design of employee voice systems, who represents and does not represent employees and the responses to such representation is a central issue in silence.

\section{Critical Management/Organisational Studies: the silent worker effort}

A second approach to silence is one of workers who silence themselves based on what are perceived to be the professional and ideological demands of their profession, emerging from the area of critical management studies/organisation studies. Brown and Coupland (2005) highlight how the training of accountants places a constraint on their speaking out about issues of concern. In contrast to the organisational behaviour approach, this approach recognises that management may actively discourage employee voice and thereby produce silence. This might be achieved through "normal pressures, ideal-types of worker and accounts of overt attempts to quieten them through notional rules and embarrassment" (Brown and Coupland, 2005: 1062). Unlike the literature reviewed in the organisational behaviour tradition, silence is seen as dialectically empowering for workers too: in this case of graduate trainees, silence functioned as a resource whereby organisational cultures discouraging of new ideas for junior personnel - effectively relieving this group from the 
responsibility to act. That silence might also be a form of power, rather than powerlessness, is evident in Fletcher and Watson (2007) who highlight that silence can actually be an important tool for workers when exercising power as per Lukes' second and third dimensions of power. In a similar vein, Dean and Greene (2017) highlight how workers in professions where there is a particular ideological vocation associated with the role, such as clergy and actors in their examples, may refrain from speaking out and view their dissatisfaction as part of the sacrifice that is paid as price for their affective commitment to that occupation. Within both these papers, the role of ideological constraints whether through managerial type or inter-worker discursive practices are highlighted. While recognising that such ideological tools may be an important part of the armoury of management in issues around the silencing of individual workers, the focus of this chapter is on how management may shape, create, and destroy structures through which types and forms of voice may be expressed.

The critical management studies (CMS) based approach to understanding worker silence addresses some of the pitfalls of the micro-dominated $\mathrm{OB}$ approach. However, much of the post-modernist strain of CMS argues workers become 'self-disciplined/consenting' subjects who willingly buy-in to improving customer service and quality (Ashcraft, 2005:69-83). It is then argued that acts such as silence, voice or even resistance function as an 'escape' into work effort (Knights et al., 1999:19-20). A problem with these interpretations is employee (and union) responses are portrayed as somewhat futile. We argue, in contrast, there are counter debates which question the extent to which voice is 'allowed' by management, and the factors at play which regulate the positions of power and authority over how much voice (and silence) management either support or withhold (e.g. Ramsey, 1977; Marchington et al., 1992). We extend employment relations analysis and labour process theory that voice and silence can be examined through the prism of the "frontier of control" (Goodrich, 1920) in that voice like other areas of the employment relationship plays a key role in terms of workplace struggles (Donaghey et al, 2011; Cullinane and Donaghey, 2014). As such, the 
issue of the extent to which workers and management contest the shape and form of issues over which there is voice or silence is a key issue in the sociology of organisations.

\section{Employment Relations and Labour Process Theory: Identifying and silencing workers}

As indicated, one of the key issues for employment relations and sociological approaches concerning labour process debates is how to evaluate something which is not readily identifiable (silence). This approach to voice has generally focussed on the identification of mechanisms, processes and institutions of worker voice and evaluating the extent to which these provide for meaningful voice or not (Dundon et al, 2004; Wilkinson et al, 2014). Methodologically, the organisational behaviour approach has generally focussed on employee surveys and asked workers to identify reasons for not speaking out on various issues. The CMS approach has generally again focussed on individual level analysis, but uses a qualitative approach to linguistic analysis and the re-interpretation of knowledge to evaluate how these organisational dynamics involve workers accepting hegemonic pressures not to speak out and even willingly embrace negative situations. In contrast, there has been some research addressing worker silence from an employment relations and labour process perspective. Wilman, Bryson and Gomez (2006) in their "Sounds of Silence" paper, using quantitative data from the UK's Workplace Employment Relations Survey test for the presence or absence of particular voice mechanisms, with the absence being used to extrapolate the presence of worker silence. Using a qualitative case study method, Graham (1993) shows how workers in a car manufacturing plant collectively mobilised against management by refusing to share information about quality and production tasks. In other words, by actively remaining silent worker effectively challenged managements' authority to intensify work effort.

However, these are not entirely satisfactory. While the presence or absence of various features may be a proxy for silence, this chapter will argue that from an employment relations perspective, an alternative approach may be insightful. This approach is one of examining where 'management 
engages in acts of silencing workers'. This differs from extrapolating the presence or absence of policies and practice, and it differs from workers either actively or unconsciously remaining silent in response to management. As Kaufman (2014:19) has suggested that while 'employees deliberately withdraw their effort or use voice in order to advance their economic position, employers actively discourage voice due to their perception that it is undesirable'. To demonstrate our approach we look at an example of where management were under a legal duty to respond to employee requests for voice and the ways in which they responded to such requests. As will be outlined, even though there was a duty enshrined in law, management actions were such as to in effect seek to circumscribe the extent to which worker voice was enacted. In particular, we highlight the role of management 'counter-mobilisation' (Kelly, 1998) in silencing workers. Kelly (1998) argues for the use of mobilisation theory as a lens to understand worker collective action: workers have divergent interests from employers, they mobilise around a collectively held grievance attributed to the action of the employer through collective organisation. This mobilisation forms around a particular opportunity to express the grievances with collective action. Kelly highlights that employers will counter-mobilise through ameliorating the source of the grievance or through more punitive tactics. This chapter argues that the mobilisation of workers led to employer responses which carried with it shared features: on the one hand, the employers made some concessions around the substantive issues which drove the grievances about voice; secondly, employer-driven voice mechanisms were established which fell short of what workers sought but were presented as being a substitute for the form which the workers sought; thirdly, after the initial pressure dissipated, these voice mechanisms were allowed to atrophy. Thus, through a counter-mobilising strategy, management were able to exercise silencing of workers.

\section{Employers Counter-Mobilisation Strategy - The research}


The research upon which this chapter looks at the implementation of the EU's Information and Consultation Directive (2002/14/EC) in the UK and Republic of Ireland. While the project did not specifically focus on silence per se but on the extent to which the Directive introduced worker voice, evidence is presented from three cases where management explicitly had to respond to requests or pressure from workers to establish more robust forms of employee representation and how management responded to such requests. In recent years, the European Commission has been prominent in advancing an indirect, collectivist route to employee voice with legislation covering works council's in multinationals, collective redundancies and a general right to information and consultation. The latter was dealt with through European Directive (2002/14/EC) on Employee Information and Consultation which emerged from the shock announcement of 3000 redundancies at the Renault Plant in Vilvoorde, Belgium, in 1997. Summarised simply, the Directive sets out the requirements for a permanent and statutory framework for employee information and consultation. Directive 2002/14/EC (European Commission, 2002) marked the introduction of workers' general right to information and consultation for the first time through standing structures across the European Union. While the situation occurred in Belgium, it was always felt that the legislation would particularly affect the voluntarist economies of the Republic of Ireland and the UK (Gollan and Wilkinson, 2007; Hall, 2005). This was because most other EU member states at the time, had mandatory works councils or similar arrangements for representative and collective voice. While the initial draft of the legislation proposed measures including the right for managerial decisions to be overturned where the levels of information and consultation were insufficient, the Directive when finally passed the EU's legislative process was much weaker in nature. In addition, the nature of EU Directives is such that a large degree of discretion is afforded to member states in terms of the ways in which they choose to implement the Directive.

Due to pre-existing legislation in most EU member states, many countries had to make little to no changes with the UK and Ireland standing out as the exceptions (Donaghey et al, 2013). While there were differences in the detail, the UK and Ireland implemented the directive in broadly similar ways. 
First, in neither state was a positive obligation placed on business to establish employee representative bodies. Rather, in both states, employers had to respond and establish a body when approximately $10 \%$ of workers signed a request for such a body. Secondly, as such, it was an example of what has been labelled as EU reflexive law where rights are to be triggered by individuals rather than positive rights per se. Thirdly, within both countries there is no significant privilege in terms of trade unions as worker representatives. Fourthly, in both countries provisions were established where "pre-existing arrangements" were to be given priority over a default model. Under this provision, companies which had for example recognised trade unions or a pre-existing Non-Union Employee Representation Scheme could claim that this should be the mechanism for fulfilling the requirements of the Directive.

The directive states that organisations will have to inform and consult with employee representatives (whether union and/or non-union) on three general areas: the economic situation of the organisation; the structure and probable development of employment (including any threats to employment); and to inform and consult on decisions likely to lead to change in work organisations or contractual relations (Hall et al. 2013). Whilst the transposition of the directive was relatively unproblematic in most EU member states, where mandatory and more taxing national works council's legislation existed, it proved more controversial in the Anglophone economies of the UK and Ireland, given the absence of a statutory system for involvement and participation and the historical dominance of voluntarist systems of employment relations (Sisson, 2002). Potentially, the net effect of the directive was, for the first time, to allow British and Irish workers a legal right to be informed and consulted on a range of business and employment issues.

On a number of levels the implementation, or non-implementation, of the Directive in the UK and Ireland is of conceptual relevance to an illumination of our arguments on the role of management in engineering spheres of employee silence. As has been established, the final transposition of the 
directive into both the UK and Irish contexts was minimalist (Hall, 2005; Dundon et al, 2006; Dundon et al, 2014). In both jurisdictions, the nature of the transposed legislation offered a substantial degree of flexibility conducive to management, which could check or minimise the emergence of potentially robust voice regimes. This derived from a mixture of government reticence and employer obstinacy which saw the directive significant diluted in transposition (Dundon et al, 2014); from one offering an absolute right to information and consultation to a right which is now only conferred when a group of workers elect to claim the right. Other noticeable areas in which the full force of the directive was restricted was the flexibility provided to employers surrounding pre-existing agreements and a recognition that direct involvement schemes would not be compromised by directive.

Whilst an initial requirement in the draft directive for enterprises to report on the 'probable economic and financial situation' of enterprises was replaced by 'probable economic situation' reducing the level of financial reporting obligations. Whilst these efforts to reduce employee voice from the remit of strategic management decision-making were largely a product of manoeuvrings at the national-level, the substance of such activities provided the template to replicate this at workplace level also. Employers have considerable flexibility of response, including relying on employee ignorance and thereby giving free scope to do nothing. Employees face difficulties when attempting to trigger the procedures and may have to fight to secure information and consultation rights (Cullinane et al, 2015; Roche and Geary, 2005). In the main, employers are unlikely to volunteer to introduce such arrangements, unless they can perceive a competitive advantage in so doing, and, outside of union strongholds, non-unionised employees may be largely unaware of these new rights. Indeed, given the manner of transposition, employers may simply be able to adopt of a policy of maintaining their existing arrangements where they consider current information and consultation machinery safe from employee challenges to set in motion the legislative process. 
Management can potentially use the formal protection provided in the regulations by having preexisting agreements in place which comply with the necessary criteria. These pre-existing agreements could be used as a vehicle to circumvent the likelihood of a potentially more robust statutory model being imposed later on. How management are responding to this legislation then remains a pertinent one and provides a highly contemporaneous avenue upon which to explore the conceptual themes around managerial silencing discussed above. The following section draws on three illustrative cases to explore these relationship.

\section{Research Case Studies}

The cases outlined in this Chapter all involved companies who explicitly addressed issues involving the implementation of the Information and Consultation Directive. In the first two, one from the UK and one from the Republic of Ireland, management used the provisions of the directive to establish a voice mechanism instead of recognising a trade union. In the third, an organisation form the Republic of Ireland, management were highly resistant to the establishment of the default provision arising from the implementing legislation in the Republic of Ireland. Thus, the legislated mechanism of voice in all three became a significant contested terrain between management-worker. What unifies all three cases is that within the establishment, workers were seeking the establishment of a more robust form of worker representation than which management were willing to cede.

\section{Case Study One - Manufacture Co}

Background

Manufacture Co is a family owned company operating in Belfast, Northern Ireland. At the time of the research, 300 people were employed in its single site with the main concentration being involved in manufacture and assembly of products. The company had expanded rapidly in the 
decade after the turn of the millennium, going from a small enterprise to being a mid-sized manufacturer. Unusually for a medium sized family owned firm in manufacturing it had a welldeveloped and well-resourced HR function. The company prided itself on the quality of its people management and high commitment human resource climate. There was extensive communication using a variety of media with shop floor employees. As the company expanded in size and in order to fulfil the requirements of the Investors in People human resources standard, the company established a non-union employee representation forum. The company specifically used the default in the Information and Consultation of Employees regulations as its template. Within a year, the forum had atrophied with neither management nor workers showing much interest: with its nature as a family firm, many of the workers instead opted to go straight to the owner family.

\section{Contesting the Terrain}

Disquiet emerged in the firm associated with a new productivity pay system and the suspension of the bonus mechanism. This saw the emergence of what was viewed by management as an aggressive union recognition campaign though estimates put trade union membership never getting much above $10 \%$ of the workforce. At this point, management re-initiated the employee forum as a mechanism to discuss issues of employee concern.

The company was non-union despite recruitment efforts in the mid-2000s by one union. Information and consultation arrangements focussed on an employee forum established under the regulations as a pre-existing agreement (PEA). It had seven employee representatives and five members of management. Notionally it met each quarter but more frequent meetings were sometimes held. A number of stimuli seemed to be associated with the founding of the forum in 2005. An accreditation body had suggested it to improve communications; some workers interviewed suggested it was an alternative to the union designed to pre-empt the regulations as a Pre-Existing Arrangement; the growth of the company required more formal communication 
methods and, most obviously, it was seen as best practice. The forum covered a wide range of topics for information and consultation including probable decisions which will have a substantial impact on aspects of employment and work organisation. Normally information papers were given to employee representatives three weeks prior to the forum meeting to allow for representatives to consult with employees, formulate their opinions and gain a response. A pre-meeting was held to aide this process. Representatives were allocated time before and after meetings to talk with their constituents. Some used time at the end of the supervisors' team briefing to report on forum matters but others do not give this part of their role much priority.

Views on the success of the Forum vary. It was highly regarded by management who valued the opportunity it gave them to explain the basis of decisions and dispel rumours. However, employees were more sceptical suggesting it was used to legitimise management behaviour. They also highlighted it could get bogged down with house-keeping matters raised by employee representatives. It also proved hard to get employees to stand as representatives and it was rare for an election to be required. On the other hand the Forum was used by employees to debate big issues such as the productivity bonus which did lead to changes in bonus design before it was frozen in economic crisis. However, this was some years ago and some representatives believe the Forum now has no influence over management and is thus seen as an irrelevance. One difficulty for representatives was how to find a distinctive role. Some believed that rather than employees raising matters directly with their supervisor they should ask the representative to deal with it. The reluctance to do this restricted their role and wider influence. This was because, it was not clear whether individual issues are appropriate topics for collective consultation. These ambiguities may reflect lack of training given to representatives. Management initiated the process with the goal of reaching active consultation. However, when faced with organisational difficulties there was a reversion to information /organisational communicator indicating that consultation only developed at a superficial level. As such the process effectively atrophied due to the lack of substantial matters it deals with and through the way management has developed and managed the relationship. 
Case Study Two - BritCo

\section{Background}

BritCo is a former state owned enterprise from the UK which was privatised by the Thatcher government in the 1980s. Following privatisation, it expanded internationally and began operating in over 80 countries across the world and began operations in Ireland in about 2000. In 2005, the company reorganised and merged its operations in Northern Ireland and the Republic of Ireland into one unit "BritCo Ireland". The company has high levels of unionisation within its UK operations, including Northern Ireland. However, for its non-UK operations, it pursues a policy of avoiding and not recognising trade unions including in the Republic of Ireland. What was notable about this arrangement was that while the company was operating in business terms as "BritCo Ireland", workers in the Northern Irish section were covered by agreement bargained collectively in the UK with the firm operating a "double-breasting" regime (Cullinane et al, 2011; Dundon et al, 2014).

Contesting the Terrain

A divergence occurred in terms and conditions of employment within the same business unit. This divergence was magnified around two issues: redundancies and pay scales. In Northern Ireland, workers were covered by a no compulsory redundancy agreement while there was no such cover for workers in the Republic of Ireland. Secondly, workers in Northern Ireland were paid according to collectively agreed pay scales whereas in the Republic of Ireland, staff were effectively on individual salaries with no pay scales, role profiles or other objective rationale to justify salary points. This led to a feeling of resentment amongst some workers in the Republic of Ireland as the more favourable terms in the North were associated with the unionised set up. 
In response to this a union organising campaign was initiated by a specific group of workers in the company. The message of the campaign was built around the unequal treatment of workers in the Republic of Ireland, compared to Northern Ireland. Within the Republic of Ireland, a non-Union Employee Representation Scheme had been established under the auspices of fulfilling the requirements of the Provision of Employee (Information and Consultation) Act 2006. However, it was viewed as being very weak and generally ineffective and had become defunct by early 2007 . With the commencement of the union recognition campaign, management decided to revamp this forum. In particular, significant effort was put into establishing electoral constituencies with approximately one representative per hundred workers. In addition, while previously the forum had become a forum for management to present information to worker representatives, workers now were given the opportunity to raise issues for inclusion on the agenda.

Two particular issues arose, the redundancy policy and issues around pay transparency. For both issues, management was insistent that the forums were clearly there for information and consultation, not negotiation. On the issue of redundancy, the forum saw a redrafting of the redundancy policy, with a significant increase in redundancy payments. However, the company insisted on having the ability to pursue compulsory redundancies in the Republic of Ireland, in contrast to Northern Ireland. With regard to pay transparency, there was little movement on the issue of pay scales. The company did introduce a new system where workers were to be told some details of pay determination but the scales remained invisible to workers with no clear criteria as to pay levels. In the short-term, the establishment of the forum and the partial addressing of the grievances at the forefront of the union organising campaign were viewed to have settled much of the disquiet. However, following this, employee representatives noted that the utility of the forum diminished and had become reduced to discussing rather mundane issues. 


\section{Case Study Three - High-TechCo ${ }^{1}$}

High-TechCo is a high end US-owned manufacturing company based in the Republic of Ireland. A profitable company, at time of the research, it had over 70 sites across five continents, employing 25,000 people. The company had three sites in Ireland employing over 4000 . The focus of the study is its largest plant facility employing close to 3000 mainly in assembly line work, which is also its largest manufacturing site in its global plant network. It has a large, well-resourced personnel department, which has received awards from professional accreditors for its people-management practices. The Company had no representative voice mechanisms in existence and there were a number of disgruntled staff who were frustrated at the way in which they perceived the company to operate in terms of communicating with staff. This small group of worker activists decided to trigger an employee request for the establishment of an Information and Consultation Forum under the Irish implementing legislation. What is notable is that this group of workers very consciously did not wish to see this as a union organising campaign and did not want to see union involvement in the campaign.

Contesting the Terrain

The workers submitted what they believed to be the required number of signatures to the Labour Relations Commission (LRC), the statutory body charged with implementing the legislation in the Republic of Ireland. In response to this, High-TechCo claimed that they had a functioning forum under the legislation for the previous four years which they claimed should be treated as a "PreExisting Arrangement" which under Irish law takes precedence over the legislation. Despite this claim from the company, there was no substantial evidence produced to verify the claims that the forum had been in existence for any substantial period. High-TechCo then circulated a request for new members to this forum with management selecting from the volunteers the workers who would

\footnotetext{
${ }^{1}$ This is a summary of the full case as presented in Cullinane et al (2015). Note that the pseudonym has been changed to maintain consistency with the other two cases presented.
} 
sit on the forum, rather than carrying out democratic elections of representatives. All those selected were of supervisory grade in the company.

The worker activists persisted in trying to establish a forum under the legislation and a series of exchanges occurred between the workers, the company and the LRC. Eventually, the company decided to hold a worker referendum to allow workers to decide which forum they wished to support. The company also decided to run representative elections which ran concurrently with the referendum. Management encouraged workers to support their preferred option and placed logistical limitations, such as preventing the activists from promoting the alternative in areas other than their own work unit and only circulating material produced by management, that prevented the activists from engaging in meaningful canvassing across the company. In addition, High-TechCo provided a FAQ sheet with the referendum that minimised differences in the two alternatives. The company refused to publicise the results of the referendum, except to say that their preferred option had secured a majority. However, two of the activists who had been organising the campaign for the alternative forum were elected as worker representatives. Shortly afterwards, both of these workers were dismissed from the Company for undocumented sick leave. Both took cases to employment tribunals for unfair dismissal with the cases settled outside the tribunal. Significantly, after the referendum result and the exit of the two worker activists, the company's attention to maintaining the forum shifted and the initiative has rather unsurprisingly withered.

\section{Discussion and conclusion}

Two key issues arise in this chapter. The first is that worker silence must be viewed over time and space and in variable macro contexts of broader understandings of the employment relationship. To view silence in terms as outlined in the prevalent organisational behaviour approach misses out on both the nuances of organisational and wider societal level dynamics where silencing essentially emerges as a managerial tactic to side-line controversial issues within the specific context of the 
employment relationship. Similarly, the CMS and organisational studies approach to worker silence risks viewing employee activities and employment structures that shape divergent interests as marginal, or worse still as futile. Within the three cases discussed, a common thread was that the response of management was that any commitment to developing representative voice was done so in a minimalist way and in response to specific pressures in the workplace: once these issues subsided, there was noticeable reduction in the commitment of management to the voice forums. In terms of responding to employee pushes for greater and more meaningful voice, organisational management adopted multiple and at times uneven approaches. On the one hand, actions over substantive issues were reinvigorated in the short term to deal with worker demands for better quality voice, including in two of the three cases reconstituted non-union employee representation forums. On the other hand, by maintaining in the medium to long term an approach which strictly limited the forums once initial grievances dissipated, the structures atrophied. As such, worker silence is more than simply workers exercising a choice over whether or not to speak out: silence is an organisational phenomenon which can be seen, in part at least, to be socially engineered to reinforce the power of employer actors. As such, the recognition that organisations are made up of a plurality of competing interests and that voice is central to the struggle and contested terrain between these voices, encourages the importance of identifying how one party can silence another party.

Secondly, empirically identifying silence can be a difficult task when silence is seen as the lack of opportunity for workers to voice their concerns. For example, can it be said just because workers don't voice their opinions or have structures through which to voice their opinions that they are silent? That said, this chapter presents an approach which highlights that silence is an issue of importance for scholars of employment relations and that focussing on cases of when and how management respond to calls for improved worker voice can be instructive in understanding how management silence workers. What makes the contribution of employment relations and wider labour process synthesis important in this area is a deeper understanding of the dynamics and 
complexities of how interests play a role in shaping mobilisation and counter-mobilisation in terms of voice mechanisms. Worker voice is a key area of employment relations research and by examining the dynamics of the voice and silence extends analysis beyond a narrow dyadic to bring broader valuable light onto the entire area of research into worker voice.

\section{References}

Ashcraft, K.L (2005), 'Resistance through Consent? Occupational Identity, Organizational Form and the Maintenance of Masculinity among Commercial Airline Pilots', Management Communication Quarterly, 19: pp.67-90.

Barry, M. and Wilkinson, A., 2016. Pro-social or pro-management? A critique of the conception of employee voice as a pro-social behaviour within organizational behaviour. British Journal of Industrial Relations, 54(2), pp.261-284.

Brown, A.D. and Coupland, C., 2005. Sounds of silence: Graduate trainees, hegemony and resistance. Organization Studies, 26(7), pp.1049-1069.

Cullinane, N. and Donaghey, J., 2014. Employee silence. In Wilkinson, A., Donaghey, J., Dundon, T. and Freeman, R (eds) "Research Handbook of employee voice", Edward Elgar

Cullinane, N., Donaghey, J., Dundon, T. and Dobbins, T., 2012. Different rooms, different voices: Double-breasting, multi-channel representation and the managerial agenda. The International Journal of Human Resource Management, 23(2), pp.368-384.

Cullinane, N., Hickland, E., Dundon, T., Dobbins, T. and Donaghey, J., 2015. Triggering employee voice under the European Information and Consultation Directive: A non-union case study. Economic and Industrial democracy, p.0143831X15584085.

Curran, D. and Quinn, M., 2012. Attitudes to employment law and the consequent impact of legislation on employment relations practice. Employee Relations, 34(5), pp.464-480.

Dean, D. and Greene, A.M., 2017. How do we understand worker silence despite poor conditions-as the actress said to the woman bishop. Human Relations, p.0018726717694371

Donaghey, J., Cullinane, N., Dundon, T. and Wilkinson, A., 2011. Reconceptualising employee silence: problems and prognosis. Work, employment and society, 25(1), pp.51-67

Donaghey, Carley, Purcell and Hall (2013) National practices of information and consultation in Europe. Eurofound: Dublin available at http://eurofound.europa.eu/sites/default/files/ef files/pubdocs/2013/29/en/3/EF1329EN.pdf

Dundon, T., Wilkinson*, A., Marchington, M. and Ackers, P., 2004. The meanings and purpose of employee voice. The International Journal of Human Resource Management, 15(6), pp.1149-1170 
Dundon, T., Curran, D., Ryan, P. and Maloney, M., 2006. Conceptualising the dynamics of employee information and consultation: evidence from the Republic of Ireland. Industrial Relations Journal, 37(5), pp.492-512

Dundon, T., Dobbins, T., Cullinane, N., Hickland, E. and Donaghey, J., 2014. Employer occupation of regulatory space of the Employee Information and Consultation (I\&C) Directive in liberal market economies. Work, employment and society, 28(1), pp.21-39

Dyne, L.V., Ang, S. and Botero, I.C., 2003. Conceptualizing employee silence and employee voice as multidimensional constructs. Journal of management studies, 40(6), pp.1359-1392

Fletcher, D. and Watson, T., 2007. Voice, silence and the business of construction: Loud and quiet voices in the construction of personal, organizational and social realities. Organization, 14(2), pp.155-174

Geary, J.F. and Roche, W.K., 2006. The future of employee information and consultation in Ireland. In Storey, J. (ed) Adding Value Through Information and Consultation. Palgrave Macmillan.

Gollan, P.J. and Wilkinson, A., 2007. Contemporary developments in information and consultation. The International Journal of Human Resource Management, 18(7), pp.1133-1144.

Goodrich, C.L., 1920. Frontier of control: a study in British workshop polities

Graham, L. (1993). Inside a Japanese Transplant: A Critical Perspective, Work and Occupations, 20: pp. 147-173.

Hall, M., 2005. Assessing the information and consultation of employees regulations. Industrial Law Journal, 34(2), pp.103-126.

Hall, M., Hutchinson, S., Purcell, J., Terry, M. and Parker, J., 2013. Promoting effective consultation? Assessing the impact of the ICE Regulations. British Journal of Industrial Relations, 51(2), pp.355-381

Kaufman, B., (2014), Theorising Determinants of Employee Voice: An Integrative Model Across Disciplines and Levels of Analysis, Human Resource Management, 25 (1): 19-40.

Kelly, J., (1998). Rethinking industrial relations: Mobilisation, collectivism and long waves. Routledge

Knights, D., D. Calvey and P. Odih (1999), 'Social Managerialism and the Time Disciplined Subject: Quality-Quantity Conflicts in a Call Centre', 17th Annual International Labour Process Conference, School of Management, Royal Holloway, University of London, 29-31 March.

Lukes, S. (1974) Power: A Radical View, 2nd edition. London: Macmillan

Marchington M., Goodman J., Wilkinson A. and Ackers P (1992). New Developments in Employee Involvement. Employment Department Research Paper Series No 2, HMSO: London.

Milliken, F.J., Morrison, E.W. and Hewlin, P.F., 2003. An exploratory study of employee silence: Issues that employees don't communicate upward and why. Journal of management studies, 40(6), pp.1453-1476

Morrison, E.W., 2011. Employee voice behavior: Integration and directions for future research. Academy of Management annals, 5(1), pp.373-412. 
Morrison, E.W. and Milliken, F.J., 2000. Organizational silence: A barrier to change and development in a pluralistic world. Academy of Management review, 25(4), pp.706-725.

Morrison, E.W. and Rothman, N.B., 2009. Silence and the dynamics of power. Voice and silence in organizations, 6 , pp.111-134

Pinder, C.C. and Harlos, K.P., 2001. Employee silence: Quiescence and acquiescence as responses to perceived injustice. In Research in personnel and human resources management (pp. 331-369). Emerald Group Publishing Limited.

Ramsay, H. (1977). Cycles of Control: Worker Participation in Sociological and Historical Perspective, Sociology, 11: pp. 481-506.

Sisson, K., 2002. The Information and Consultation Directive: Unnecessary" regulation" Or an Opportunity to Promote" partnership"? Industrial Relations Research Unit, Warwick Business School.

Van Dyne, L. and LePine, J.A., 1998. Helping and voice extra-role behaviors: Evidence of construct and predictive validity. Academy of Management journal, 41(1), pp.108-119

Wilkinson, A., Dundon, T., Donaghey, J. and Freeman, R., 2014. Employee voice: Charting new terrain. In Wilkinson, A, Donaghey, J, Dundon, T and Freeman, R (eds) The handbook of research on employee voice: Participation and involvement in the workplace, pp.1-16

Willman, P., Bryson, A. and Gomez, R., 2006. The sound of silence: which employers choose no employee voice and why? Socio-Economic Review, 4(2), pp.283-299 